\title{
Radon exhalation from phosphogypsum stabilized in sulfur polymer cement
}

\author{
Irene García-Diaz ${ }^{1^{*}}$, Francisco José Alguacil ${ }^{1}$, Manuel Gázquez ${ }^{2}$, Juan Pedro Bolivar ${ }^{2}$, \\ Israel López Coto ${ }^{2}$, Félix A. López ${ }^{1}$ \\ ${ }^{1}$ Centro Nacional de Investigaciones Metalúrgicas (CENIM), CSIC, Avda. Gregorio del Amo, Madrid, Spain; \\ *Corresponding Author: irenegd@cenim.csic.es \\ ${ }^{2}$ Departamento de Física Aplicada, Universidad de Huelva, Campus del El Carmen, Huelva, Spain
}

Received 8 March 2013; revised 10 April 2013; accepted 25 April 2013

Copyright (C) 2013 Irene García-Diaz et al. This is an open access article distributed under the Creative Commons Attribution License, which permits unrestricted use, distribution, and reproduction in any medium, provided the original work is properly cited.

\begin{abstract}
Phosphogypsum (PG), primary by-product from phosphoric acid production, is accumulated in large stock-piles which were active until 2010, when spills were banned. It is considered as NORM material that contains radionuclides from ${ }^{238} U$ and decay series which are of most radiotoxicity. PG was valorized and/or recycled in a building material, sulfur polymer cement (SPC). The SPC-PG samples reach the international regulation to use in the manufacture of building materials without radiological restrictions, except the sample with the $50 \%$ of PG. Under normal conditions of ventilation the contribution to the expected radon indoor concentration is also below the international recommendation.
\end{abstract}

Keywords: Radon; Phosphogypsum; NORM; Radioactivity; Sulfur polymer Cement

\section{INTRODUCTION}

The phosphate rock, due to its origin, is affected by high concentration of impurities, heavy metals, naturally occurring radionuclides and other so-called trace elements. A common mineral in phosphate rock is the carbonate fluorapatite, in which up to the $0.02 \% \mathrm{U}$ can substitute for positions typically occupied by atoms of calcium in the structure [1]. The phosphate rock is treated with sulfuric acid to produce phosphoric acid by the dihydrate process according to Eq.1 [2,3]. During this process is also produced a by-product called phosphorgypsum (PG).

$$
\begin{aligned}
& \mathrm{Ca}_{10}\left(\mathrm{PO}_{4}\right)_{6} \mathrm{~F}_{2} \mathrm{CO}_{3} \mathrm{Ca}+\mathrm{H}_{2} \mathrm{SO}_{4}+21 \mathrm{H}_{2} \mathrm{O} \\
& \rightarrow 6 \mathrm{H}_{3} \mathrm{PO}_{4}+11 \mathrm{CaSO}_{4} \cdot 2 \mathrm{H}_{2} \mathrm{O}+2 \mathrm{HF}+\mathrm{CO}_{2}
\end{aligned}
$$

The composition of PG is dominated by gypsum, impurities including $\mathrm{Al}, \mathrm{P}, \mathrm{F}, \mathrm{Si}, \mathrm{Fe}, \mathrm{Mg}$ as well naturallyoccurring radionuclides which originate mainly from the phosphate rock used in the processing. Concentration of these hazardous elements, may vary mainly depending on the origin of the phosphate rock and to a lesser extent, on factor such as plant generation and PG age [4].

Most sedimentary phosphate rock deposits contain elevated levels of radionuclides from ${ }^{238} \mathrm{U}$ in secular equilibrium with its daughters [5]. Chemical processing of the phosphate rock in order to produce phosphoric acid, results in a fractionation into the acids and PG of radioelement contained in phosphate rock [6]. The phosphogypsum contains specific activities of ${ }^{226} \mathrm{Ra}$, the decay chain segment in the uranium series, between one and two orders of magnitude higher than the natural gypsum depending on the uranium content of the rock [7].

The radium 226 has a half life of 1620 years and is the long-term source radioactivity in most PG. One of the major concerns of materials which contain enhanced levels of ${ }^{226} \mathrm{Ra}$ is the production of ${ }^{222} \mathrm{Rn}$ gas. ${ }^{222} \mathrm{Rn}$ and its short-lived decay products are the most important contributor to human exposure to ionizing radiation which can causes health damages.

Due to the radionucleides concentration the by-products, PG, is considered as NORM material (Naturally Occurring Radioactive Materials) $[8,9]$.

Large quantities of PG are produced, the world production was $200-280 \times 10^{6}$ t per year [10]. Several phosphate processing plants are located on the south-western coast of Spain (on the outskirts of the town of Huelva) close to the estuary of the Odiel and Tinto rivers, where phosphoric acid has been produced since 1968. The company imports sedimentary phosphate rocks from Morocco, which mainly contain around $100-150 \mathrm{ppm}$ of $\mathrm{U}$ [3]. Until 2010 the PG production at Huelva was around $3 \times$ 
$10^{6} \mathrm{t}$ per year [11]. This by-product was accumulated in regulated stock-piles and occupied vast areas of land, located in the town's surroundings with the consequent environmental problem.

Therefore the waste and the by-products are gaining more and more attention nowadays, such research and/or production is being carried out to the incorporation of these wastes and by-products (fly ash, red mud, coal slag, ceramic waste) as building material [12-15].

The sulfur polymer cement, SPC, has been used in civil engineering (column supports, pump foundations, walls in storage areas, etc.) due to its excellent properties, which for certain applications are superior to ordinary Portland cement (OPC). The SPC presents high durability and fast setting time and rapid gain of high strength, achieving most of its mechanical strength in less than 1 day of curing. It has also recently emerged as a possible alternative as a binding and stabilizing agent for the solidification and stabilization of hazardous, low-level radioactive and mixed wastes [16].

Due to the relatively high levels of natural radionucleides in the PG an important radiation exposure could be received from building materials containing this byproduct. This implies the need to control it.

Different international recommendations propose reference values of the natural radionuclide concentrations in building materials (Publication No. 112 from monographic collection "Radiation Protection" issued by the European Union) [17]. The activity concentration index (I), is calculated on the bases of the activity concentrations of radium $\left({ }^{226} \mathrm{Ra}\right)$ in the uranium $\left({ }^{238} \mathrm{U}\right)$ decay series, radium $\left({ }^{238} \mathrm{Ra}\right)$ in the thorium $\left({ }^{232} \mathrm{Th}\right)$ decay series and potassium $\left({ }^{40} \mathrm{~K}\right)$, Eq.2. I index ensures that external gamma dose rate inside de room from building materials does not exceeded $1 \mathrm{mSv}$ per year, Table 1. When the gamma dose are limited to levels below $1 \mathrm{mSV}$ per year, the ${ }^{226} \mathrm{Ra}$ concentration in the materials are limited, to levels which are unlike to cause indoor radon concentration exceeding the design level of $200 \mathrm{~Bq} \cdot \mathrm{m}^{-3}$.

$$
I=C\left({ }^{226} \mathrm{Ra}\right) / 300+C\left({ }^{228} \mathrm{Ra}\right) / 200+C\left({ }^{40} \mathrm{~K}\right) / 3000
$$

where $C\left({ }^{226} \mathrm{Ra}\right), C\left({ }^{228} \mathrm{Ra}\right), C\left({ }^{40} \mathrm{~K}\right)$ are the activity concentrations for ${ }^{226} \mathrm{Ra},{ }^{228} \mathrm{Ra}$ and ${ }^{40} \mathrm{~K}$, respectively in the building material considered, expressed in $\mathrm{Bq} \cdot \mathrm{Kg}^{-1}$.

Other countries considered to the radiological control of building material the equivalent radium concentration parameter, $\operatorname{Ra}(\mathrm{eq})$, which is shown in Eq.3:

$$
\mathrm{Ra}(\mathrm{eq})=C\left({ }^{226} \mathrm{Ra}\right)+1.43 C\left({ }^{228} \mathrm{Ra}\right)+0.077 C\left({ }^{40} \mathrm{~K}\right)(3)
$$

The reference value for $\mathrm{Ra}(\mathrm{eq})$ in many countries for building materials is $370 \mathrm{~Bq} \cdot \mathrm{kg}^{-1}$ [18]. The radon-222 and its short-lived daughters contributions are on $50 \%$ of the total natural effective dose received by the population [19]. As a consequence, many countries have established reference levels for radon in houses and work places, being these values of 200 and $400 \mathrm{~Bq} \cdot \mathrm{m}^{-1}$, respectively.

So the main objective of this research was to evaluate the radiological impact of phosphogypsum stabilized in sulfur polymer cement.

\section{EXPERIMENTAL}

Various SPC samples were studied. These were obtained by a mix of different proportions of phosphogypsum, sulfur, gravel, sand and a thermoplastic material used as modified sulfur containing polymer [20], Table 2. The SPC samples were manufactured according to López et al. [21].

The ratio of gravel/sand and sulfur/modified sulfur $\left(\mathrm{STX}^{\mathrm{TM}}\right)$ was maintained constant at 0.5 and 10 respectively. These relations are the best condition for the viscosity and workability of the mixture [21,22].

Phosphogypsum has been added to the mixtures at dosages between 10 and $50 \mathrm{wt} \%$.

Each sample was called as SPC X-Y where " $\mathrm{X}$ " is the percentage wt\% of elemental sulfur and " $\mathrm{Y}$ " is the percentage $\mathrm{wt} \%$ of phosphogypsum of the mixtures.

The SPC sample reference, SPC 21 - 0, was manufactured as to the PG-SPC samples, but in this case, calcium carbonate (99.5\% purity, Panreac) was added as filler in substitution of $\mathrm{PG}$.

\subsection{Measurement of Radionuclides}

A gamma spectrometry system with an XtRa coaxial germanium detector (Canberra), which has a 38\% relative

Table 1. Dose criteria recommendation to activity concentration index (I).

\begin{tabular}{ccl}
\hline $0.3 \mathrm{mSV} /$ year & $1.0 \mathrm{mS} /$ per year & \multicolumn{1}{c}{ Uses } \\
\hline $\mathrm{I} \leq 0.5$ & $\mathrm{I} \leq 1$ & $\begin{array}{l}\text { Materials used in bulk amount, } \\
\text { e.g. concrete, cement etc. } \\
\text { Material superficial and other } \\
\text { materials with restricted use, } \\
\text { e.g. tiles, boards etc. }\end{array}$ \\
\hline
\end{tabular}

Table 2. Composition of SPC samples (wt\%) and sulfur/PG ratio.

\begin{tabular}{ccccccc}
\hline Samples & Sulfur (S) & Gravel & Sand & PG & S $^{\text {STX }}$ & S/PG \\
\hline SPC 21-0 & 21.0 & 23.1 & 46.1 & 0.0 & 2.1 & 0.00 \\
SPC 17-10 & 17.0 & 23.8 & 47.5 & 10.0 & 1.7 & 1.70 \\
SPC 19-20 & 19.0 & 19.7 & 39.4 & 20.0 & 1.9 & 0.95 \\
SPC 21-30 & 21.0 & 15.6 & 31.3 & 30.0 & 2.1 & 0.70 \\
SPC 26-40 & 26.0 & 10.5 & 20.9 & 40.0 & 2.6 & 0.65 \\
SPC 30-50 & 30.0 & 5.7 & 11.3 & 50.0 & 3.0 & 0.60 \\
\hline
\end{tabular}


efficiency, and FWHM of $0.95 \mathrm{keV}$ at the $122 \mathrm{keV}$ line of ${ }^{57} \mathrm{Co}$ and $1.9 \mathrm{keV}$ at the $1333 \mathrm{keV}$ line of ${ }^{60} \mathrm{Co}$ were used to the radioactive characterization. The detector was coupled to a conventional electronic chain, including a multichannel analyser and was shielded with $\mathrm{Fe} 15 \mathrm{~cm}$ thick. The samples were dried at $60^{\circ} \mathrm{C}$ and grounded. The whole procedure of calibration and this gamma spectrometry system are described elsewhere [18].

\subsection{Radon Potential and Bulk Exhalation Measurements}

The radon exhalation is the radon flow released through the available surfaces $\left(\mathrm{Bq} \cdot \mathrm{m}^{-2} \cdot \mathrm{h}^{-1}\right)$, influenced by the material geometry and the boundary conditions. On the other hand, the radon potential is defined as the radon concentration generated inside the material and that is available to be transported through its pores.

The method to measure the radon potential and the emanation factors is described by López-Coto et al. [19]. From growth curves of radon inside a closed chamber it is possible to calculate the exhalation rate of the block and, under specific experimental conditions, the radon potential of the tested material. In addition, once crushed a portion of the specimen (about one third), from a second measurement in the chamber for obtaining radon potential and the real emanation factor of the material.

\subsection{Radon Transport Simulations}

The equation of radon conservation in the building material has allowed us to develop a 3D model of diffusive transport in porous media. This model has been solved for two geometries; a block of $0.04 \times 0.04 \times 0.16$ $\mathrm{m}^{3}$ and a plate of $1 \times 1 \times 0.04 \mathrm{~m}^{3}$, which was carried out by using a numerical algorithm based on finite elements on an unstructured tetrahedral mesh.

Knowing the exhalation rate of the building materials used to construct a specific room, it is possible by modeling to estimate the expected radon concentration in this room under certain ventilation conditions [23]. In this sense, it has been applied a simple model of radon accumulation in a standard room of $5 \times 5 \times 2 \mathrm{~m}^{3}$ coated on all sides by plates of the same material.

\section{RESULT AND DISCUSSION}

\subsection{Activity Concentration and Index Risk}

Table 3 shows the radionuclide concentration of PG and SPC samples. Prior to possible use of PG-SPC as building materials, a preliminary radiological analysis have been carried out in order to reliably assess the radiation dose. Attending to these results it will be possible to decide whether these materials can be used, from a radiological point of view.

The activity concentrations of ${ }^{238} \mathrm{U}$ and ${ }^{226} \mathrm{Ra}$ in the pure PG sample are around 100 and $600 \mathrm{~Bq} \cdot \mathrm{kg}^{-1}$ respectively, these values are in agreement with typical values given in the literature for PGs from Huelva [24], which are significantly higher than the average world-wide values from soils $\left(25 \mathrm{~Bq} \cdot \mathrm{kg}^{-1}\right.$ of ${ }^{238} \mathrm{U}$ and daughters $)$ [25].

The radionuclides with the highest activity concentration in the SPC samples are ${ }^{226} \mathrm{Ra}$ (and its daughters of small half live: ${ }^{222} \mathrm{Rn}{ }^{218} \mathrm{~Pb},{ }^{218} \mathrm{Bi},{ }^{214} \mathrm{~Pb},{ }^{214} \mathrm{Bi}$, etc.), and ${ }^{40} \mathrm{~K}$.

Linear decrease in activity concentration of ${ }^{40} \mathrm{~K}$ at increases the PG content in the sample it is observed, Figure 1. It is due to the very low content of potassium in PG $\left(<18 \mathrm{~Bq} \cdot \mathrm{kg}^{-1}\right.$ of ${ }^{40} \mathrm{~K}$, i.e., $<0.06 \%$ of natural potassium). The concentration of ${ }^{40} \mathrm{~K}$ in all SPC-PG samples remains below the world average of ${ }^{40} \mathrm{~K}$ from soil, $400-500 \mathrm{~Bq} \cdot \mathrm{kg}^{-1}$, only SPC $17-10$ slightly exceeds this value.

Figure 1 shows a strong lineal dependence $\left(r^{2}=\right.$

Table 3. Radionuclide concentration of SPC samples and PG $\left(\mathrm{Bq} \cdot \mathrm{Kg}^{-1}\right)$.

\begin{tabular}{lccccccc}
\hline Code & SPC $21-0$ & SPC $17-10$ & SPC $19-20$ & SPC $21-30$ & SPC $26-40$ & SPC 30 - 50 & PG \\
\hline$\% \mathrm{PG}$ & 0 & 10 & 20 & 30 & 40 & 50 & 100 \\
${ }^{210} \mathrm{~Pb}$ & $8.0 \pm 0.6$ & $70 \pm 5.0$ & $143 \pm 9.0$ & $219 \pm 13.0$ & $264 \pm 16.0$ & $340 \pm 20.0$ & $624 \pm 37.0$ \\
${ }^{238} \mathrm{U}\left({ }^{234} \mathrm{Th}\right)$ & $12 \pm 2.0$ & $21 \pm 2.0$ & $12 \pm 2.0$ & $38 \pm 3.0$ & $50 \pm 4.0$ & $60 \pm 4.0$ & $97 \pm 6.0$ \\
${ }^{232} \mathrm{Th}\left({ }^{212} \mathrm{~Pb}\right)$ & $9.1 \pm 0.6$ & $9.4 \pm 0.7$ & $8.6 \pm 0.6$ & $8.1 \pm 0.5$ & $5.9 \pm 0.4$ & $5.8 \pm 0.4$ & $8.2 \pm 1.0$ \\
${ }^{226} \mathrm{Ra}$ & $7.4 \pm 0.5$ & $63 \pm 4.0$ & $115 \pm 7.0$ & $179 \pm 11.0$ & $226 \pm 13.0$ & $282 \pm 17$ & $589 \pm 34.0$ \\
${ }^{228} \mathrm{Th}$ & $8.8 \pm 0.8$ & $8.7 \pm 0.7$ & $<6$ & $6.8 \pm 0.7$ & $7.3 \pm 0.6$ & $6.1 \pm 0.6$ & $7.8 \pm 0.7$ \\
${ }^{228} \mathrm{Ra}\left({ }^{228} \mathrm{Ac}\right)$ & $8.2 \pm 0.8$ & $8.6 \pm 0.8$ & $8.8 \pm 0.8$ & $6.9 \pm 0.7$ & $<4$ & $<4$ & $8 \pm 1.0$ \\
${ }^{40} \mathrm{~K}$ & $580 \pm 30.0$ & $528 \pm 32.0$ & $394 \pm 24.0$ & $347 \pm 21$ & $239 \pm 15.0$ & $143 \pm 10.0$ & $<18$ \\
$\mathrm{Index}$ & 0.26 & 0.43 & 0.56 & 0.75 & 0.85 & 1.01 & 2.01 \\
$\mathrm{Ra}(\mathrm{eq})\left(\mathrm{Bk} \cdot \mathrm{Kg}^{-1}\right)$ & 63 & 117 & 253 & 158 & 217 & 301 & 600 \\
\hline
\end{tabular}




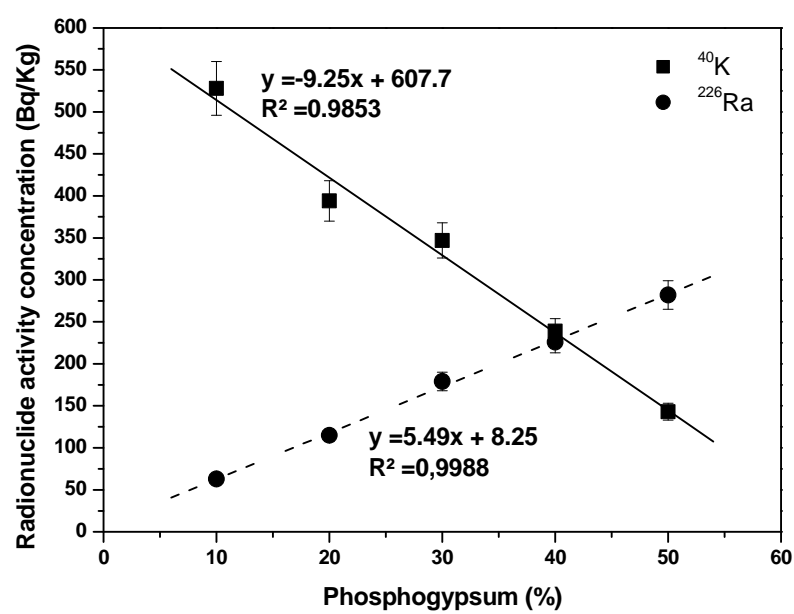

Figure 1. Variation of activity concentration of ${ }^{40} \mathrm{~K}$ and ${ }^{226} \mathrm{Ra}$ $\left(\mathrm{Bq} \cdot \mathrm{kg}^{-1}\right)$ with content of PG in the SPC samples.

0.9988) between the percentage of PG added and the activity concentration of ${ }^{226} \mathrm{Ra}$. To the value of $\mathrm{x}=0 \%$ $\mathrm{PG}$, the activity concentrations obtained is very low, around $8 \mathrm{~Bq} \cdot \mathrm{kg}^{-1}$ of ${ }^{226} \mathrm{Ra}$, similar to ${ }^{226} \mathrm{Ra}$ activity concentration in SPC 21 - 0. On the contrary, if we considering $\mathrm{x}=100 \%$, pure $\mathrm{PG}$, it is obtained an activity concentration for ${ }^{226} \mathrm{Ra}$ of $557 \mathrm{~Bq} \cdot \mathrm{kg}^{-1}$, value very similar to indicated in Table 3 for PG sample, $589 \mathrm{~Bq} \cdot \mathrm{kg}^{-1}$. These considerations can be also used to ratify the radiometric measuring methods applied to the studied samples.

The SPC-PG samples contain radioactive nuclides if the sulfur polymer cements are used as building materials, it must be confirmed that the action level of 1 $\mathrm{mSV} \cdot$ year $^{-1}$ is not be exceeded.

So, in relation to the radiological assessment, according to the recommendations of the radioactivity protection commission of EU [17], the activity concentration index (I) in the studied samples are agree with the EU references values the range of $0.3-1 \mathrm{mSv} \cdot \mathrm{a}^{-1}$ (Table 1). Only SPC $30-50$, with the $50 \%$ of PG, presents an I value around 1 , so this could not be used in bulk amounts. On the other hand, the values of $\mathrm{Ra}(\mathrm{eq})$ for all samples are below the set limit of $370 \mathrm{~Bq} \cdot \mathrm{kg}^{-1}[18,19]$, which is the limit considered in USA to building materials.

\subsection{Radon Potential and Exhalation Rate of Matrix and Blocks}

The emanation factor is the fraction of radon produced in the material that is free to be transported through its pores. The product of radium concentration per the emanation factor is the radon potential, $\mathrm{Rn}$ Pot, it is characteristic of the material and is not influenced by the experimental conditions during its determination. Rn Pot is a suitable parameter for classifying/comparing porous material in relation to its potential radon radiological risk [26]. Table 4 shows the results of radon potential and the emanation factor for PG and SPC in milled samples.

The highest value of $\mathrm{Rn}$ Pot is obtained to the pure PG sample, $68.4 \mathrm{~Bq} \cdot \mathrm{kg}^{-1}$. An increase in the fraction of $P G$ in the PG-SPC samples increases the $\mathrm{Rn}$ Pot, with ranging values from 10.3 to $30.6 \mathrm{~Bq} \cdot \mathrm{kg}^{-1}$. On the other hand, the emanation factors are very similar for all samples, including $\mathrm{PG}$, with values ranging from 0.1 and 0.16 .

The evaluation of apparent emanation factor was also studied, Table 4. This parameter is affected by the structural change in the solid sample. The SPC-PG samples show an Ea always lower than the original components for its manufacturing, because the curing process significantly reduces the emanation factor.

Table 5 shows the values of radon exhalation, E, in the SPC-PG blocks. These values are in the order of magnitude of the detection limit of the measurement system, being the uncertainties associated relatively high. However, these measurements allow to verify the low radon exhalation rates obtained in any case exceed of 5 $\mathrm{Bq} \cdot \mathrm{m}^{-2} \cdot \mathrm{h}^{-1}$.

The diffusion coefficient was also studied, Table 5. It is a parameter characteristic of radon diffusion flow. Lower values of $\mathrm{Db}$ indicated a less radon diffusion flow.

Table 4. Radon potential, Rn Pot, apparent emanation factor, Ea and radon emanation factor, $\operatorname{Ef}(\sigma$ and $\Sigma$ are their standard deviations).

\begin{tabular}{cccccc}
\hline \multicolumn{5}{c}{ Milled samples } \\
\hline Sample & Rn Pot & $\sigma$ & Ea & Ef & $\boldsymbol{\Sigma}$ \\
& $\mathrm{Bq} \cdot \mathrm{kg}^{-1}$ & $\mathrm{~Bq} \cdot \mathrm{kg}^{-1}$ & & & \\
SPC 17 - 10 & 10.3 & 0.9 & 0.015 & 0.164 & 0.020 \\
SPC 19 - 20 & 11.3 & 1.0 & 0.08 & 0.098 & 0.012 \\
SPC 21 - 30 & 22.3 & 1.7 & 0.08 & 0.132 & 0.014 \\
SPC 26 - 40 & 19.1 & 1.0 & 0.07 & 0.084 & 0.007 \\
SPC 30 - 50 & 30.6 & 1.7 & 0.05 & 0.108 & 0.009 \\
PG & 68.4 & 4.2 & & 0.116 & 0.011 \\
\hline
\end{tabular}

Table 5. Radon exhalation, E ( $\sigma$ is standard deviations), and diffusion coefficient, $\mathrm{Db}$, calculated for blocks, $0.04 \times 0.04 \times$ $0.16 \mathrm{~m}^{3}$.

\begin{tabular}{|c|c|c|c|}
\hline Sample & $\mathbf{E}$ & $\sigma$ & Db \\
\hline & $\mathrm{Bq} \cdot \mathrm{m}^{-2} \cdot \mathrm{h}^{-1}$ & $\mathrm{~Bq} \cdot \mathrm{m}^{-2} \cdot \mathrm{h}^{-1}$ & $\mathrm{~m}^{2} \cdot \mathrm{s}^{-1}$ \\
\hline SPC $17-10$ & 1.0 & 3.8 & $4.58 \times 10^{-8}$ \\
\hline SPC 19 - 20 & 1.0 & 3.8 & $2.27 \times 10^{-8}$ \\
\hline SPC $21-30$ & 1.4 & 0.9 & $4.24 \times 10^{-8}$ \\
\hline SPC $26-40$ & 1.5 & 0.9 & $6.57 \times 10^{-8}$ \\
\hline SPC $30-50$ & 1.5 & 1.0 & $1.24 \times 10^{-7}$ \\
\hline
\end{tabular}


The sample with $50 \%$ of PG, SPC $30-50$, presents the higher value $1.24 \times 10^{-7} \mathrm{~m}^{2} \cdot \mathrm{s}^{-1}$.

\subsection{Simulation by Modeling of Exhalation Rates}

It has been carried out by modeling a simulation of a block of polymer cement (SPC 30 - 50) that emanates through all its sides excepting for the base $(0.04 \times 0.16$ $\mathrm{m}^{2}$ ). The blocks not have a radon exhalation rate uniform, showing the geometry effect of this parameter, Figure 2. In turn, the mean value for radon exhalation throughout its surface in contact with air is $3.6 \pm 1.6 \mathrm{~Bq} \cdot \mathrm{m}^{-2} \cdot \mathrm{h}^{-1}$, very similar to the experimental values ones.

This model was applied to different plate $1 \times 1 \times 0.04$ $\mathrm{m}^{3}$ made off SPC-PG samples, the exhalation rates range, Table 5, were from 4 to $12 \mathrm{~Bq} \cdot \mathrm{m}^{-2} \cdot \mathrm{h}^{-1}$, being of the same order of magnitude or slightly higher of typical building materials, which have a range of $1-10$ $\mathrm{Bq} \cdot \mathrm{m}^{-2} \cdot \mathrm{h}^{-1}$ [27-29].

The plate made with SPC 30 - 50 present the highest mean values for the exhalation rate, $11.7 \pm 1.4 \mathrm{~Bq} \cdot \mathrm{m}^{-2} \cdot \mathrm{h}^{-1}$, assuming an exhalation only in one side, it is due to the highest Rn Pot values, $30.6 \mathrm{~Bq} \cdot \mathrm{kg}^{-1}$. Figure 2 shows the radon exhalation rates obtained for different surface points of plate SPC 30 - 50, the highest values are founded near the edges of the plate. Thus, the central part of the plate presents a value of $9 \mathrm{~Bq} \cdot \mathrm{m}^{-2} \cdot \mathrm{h}^{-1}$, while their edges have values until above $15 \mathrm{~Bq} \cdot \mathrm{m}^{-2} \cdot \mathrm{h}^{-1}$.

The expected radon concentration inside a standard room $\left(5 \times 4 \times 2.5 \mathrm{~m}^{3}\right)$ built with the plates shown in Figure 3, is presented in Table 6. In the standard room with a good ventilation (air enhance, $\lambda_{\mathrm{v}}=2 \mathrm{~h}^{-1}$ ) the highest expected radon concentration is reached inside the room with SPC $30-50$, sample with $50 \%$ of PG, $C_{R n}=10$ $\mathrm{Bq} \cdot \mathrm{m}^{-3}$, but this value not exceeded the average radon

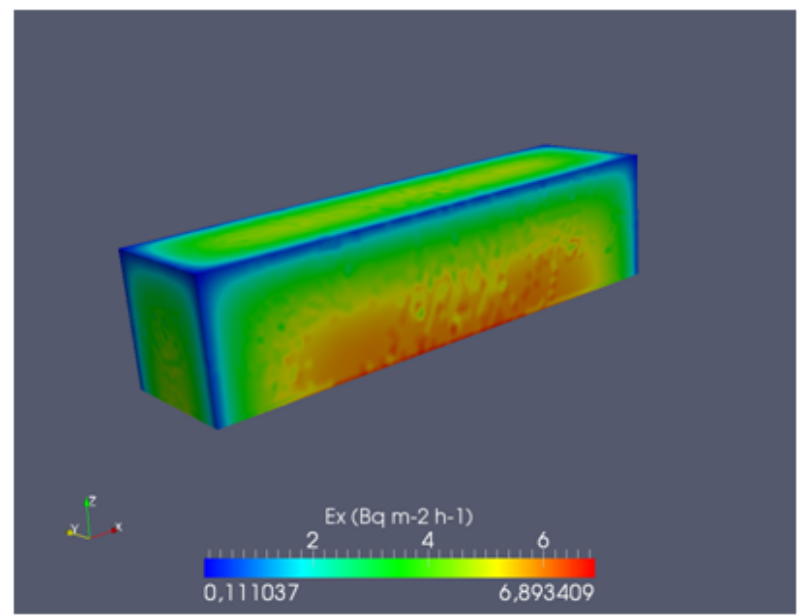

Figure 2. Radon exhalation rate obtained by modeling a specimen of $0.04 \times 0.04 \times 0.16 \mathrm{~m}^{3}$ made with SPC $30-50$ samples.

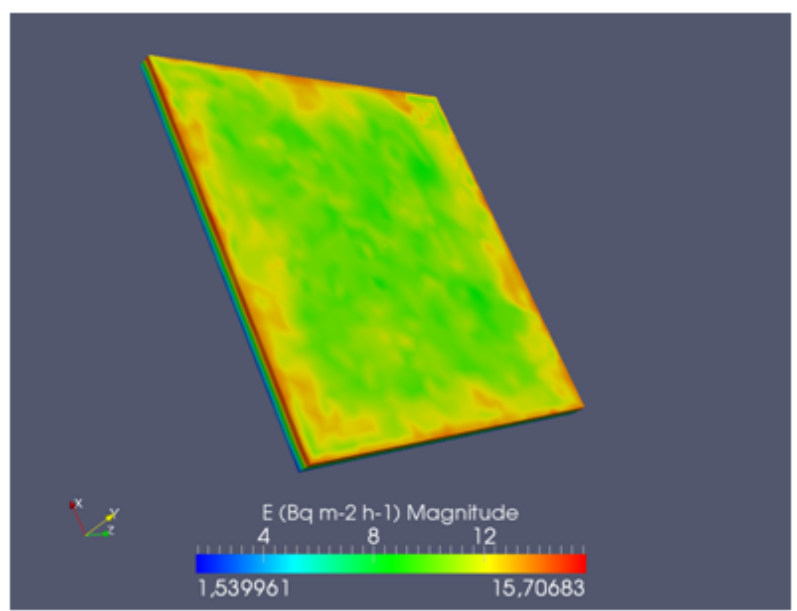

Figure 3. Radon exhalation rate obtained for different surface points of plate $\left(1 \times 1 \times 0.04 \mathrm{~m}^{3}\right)$ of SPC $30-50$ samples.

Table 6. Radon exhalation rate $(E)$ of a plate $\left(1 \times 1 \times 0.04 \mathrm{~m}^{3}\right)$ and the expected radon concentration $\left(\mathrm{C}_{\mathrm{Rn}}\right)$ in a standard room.

\begin{tabular}{|c|c|c|c|c|}
\hline \multicolumn{5}{|l|}{ Sample } \\
\hline & $\mathbf{E}$ & $\sigma$ & $\begin{array}{c}\mathbf{C}_{\mathbf{R n}} \\
\left(\lambda_{v}=2 \mathbf{h}^{-1}\right)\end{array}$ & $\begin{array}{c}\mathrm{C}_{\mathrm{Rn}} \\
\left(\lambda_{v}=0.1 \mathrm{~h}^{-1}\right)\end{array}$ \\
\hline & $\mathrm{Bq} \cdot \mathrm{m}^{-2} \cdot \mathrm{h}^{-1}$ & $\mathrm{~Bq} \cdot \mathrm{m}^{-2} \cdot \mathrm{h}^{-1}$ & $\mathrm{~Bq} \cdot \mathrm{m}^{-3}$ & $\mathrm{~Bq} \cdot \mathrm{m}^{-3}$ \\
\hline $\begin{array}{c}\text { SPC } \\
17-10\end{array}$ & 4.0 & 0.5 & 4 & 67 \\
\hline $\begin{array}{c}\text { SPC } \\
19-20\end{array}$ & 4.4 & 0.5 & 4 & 74 \\
\hline $\begin{array}{c}\text { SPC } \\
21-30\end{array}$ & 8.7 & 1.1 & 8 & 146 \\
\hline $\begin{array}{c}\text { SPC } \\
26-40\end{array}$ & 7.5 & 0.9 & 7 & 125 \\
\hline $\begin{array}{c}\text { SPC } \\
30-50\end{array}$ & 11.7 & 1.4 & 10 & 196 \\
\hline
\end{tabular}

concentrations to $200 \mathrm{~Bq} \cdot \mathrm{m}^{-3}$, reference value in the $\mathrm{EU}$ for new houses. Under poor ventilation $\left(\lambda_{\mathrm{v}}=0.1 \mathrm{~h}^{-1}\right)$ the average radon concentrations increases. In SPC $30-50$ the radon concentration achieved was $196 \mathrm{~Bq} \cdot \mathrm{m}^{-3}$, this value is very similar to the reference value in the $\mathrm{EU}$, $200 \mathrm{~Bq} \cdot \mathrm{m}^{-3}$.

\section{CONCLUSIONS}

The activity concentration indexes, I, in the SPC-PG samples are lower than the reference value, not exceeding the $1 \mathrm{mSV} \cdot$ year $^{-1}$. Therefore, these cements can be used without radiological restrictions in the manufacture of building materials, except in the sample with the $50 \%$ of PG.

On the other hand, the equivalent radium concentration, $\mathrm{Ra}(\mathrm{eq})$, in all the SPC samples have values less than the reference values set by the EPA for constructions materials $\left(370 \mathrm{~Bq} \cdot \mathrm{kg}^{-1}\right)$. The higher values of $\mathrm{Ra}(\mathrm{eq})$ are obtained in SPC $30-50$.

Under normal conditions of ventilation, the contribu- 
tion to the expected radon indoor concentrations is below the international recommendations for indoor radon, so the building materials studied in this work can be applied in the house' construction under normal ventilation conditions.

\section{ACKNOWLEDGEMENTS}

The authors are grateful to the Spanish National R\&D\&I Plan (Projects CTQ200802012/PPQ and P10-RNM6300) for the financial support of this study and to Mr. Carlos Pérez for technical assistance. Dr. I. García-Díaz expresses her gratitude to the Spanish National Research Council (CSIC) for her contract through the JAE Program (JAE Doc09-00893), co-financed by the European Social Fund.

\section{REFERENCES}

[1] Landa, E.R. (2007) Naturally occurring radionuclides from industrial sources: Characteristic and fate in the environment. Radioactivity in the Environment, 10, 121-237.

[2] Fertiberia (2002) Documentation on the industrial process at the Huelva phosphoric acid production plant. Fertiberia, S.A. (in Spanish).

[3] Bolivar, J.P., Martín, J.E., García-Tenorio, R., Pérez-Moreno, J.P. and Mas J.L. (2009) Behaviour and fluxes of natural raionuclides in the production process of a phosphoric acid plant. Applied Radiation and Isotopes, 67, 345-356. doi:10.1016/j.apradiso.2008.10.012

[4] Renteria-Villalobos, M., Vioque, I., Mantero, J. and Majón, G. (2010) Radiological, chemical and morphological characterization of phosphate rock and phosphogypsum from phosphoric acid factories in SW Spain. Journal of Hazardous Materials, 182, 193-203. doi:10.1016/j.jhazmat.2010.04.116

[5] Lardinoye, M.H, Weterings, K. and Van der Bergn, W.B. (1982) Unexpected Ra-226 build up in wet phosphoricacids plants. Health Physics, 42, 503-514. doi:10.1097/00004032-198204000-00011

[6] Rutherford, P.M., Dudas, M.J. and Arocena, J.M. (1996) Heterogeneous distribution of radionuclides, barium and strontium in phosphogypsum by-products. The Science of the Total Environment, 180, 201-209. doi:10.1016/0048-9697(95)04939-8

[7] Papastefanou, C., Stoulos, S. and Monolopoulu, M. (2005) The radioactivity of building materials. Journal of Radionalytical and Nuclear Chesmistry, 266, 367-372. doi:10.1007/s10967-005-0918-Z

[8] El Afifi, E.M., Hilal, M.A., Khalifa, S.M. and Aly, H.F. (2006) Evaluation of U, Th, K and emanated radon in some NORM and TENORM samples. Radiation Measurements, 41, 627-633. doi:10.1016/j.radmeas.2005.09.014

[9] El-Didamony, H., Gado, H.S., Awwad, N.S., Fawzy, M.M. and Attallah, M.F. (2013) Treatment of phosphogypsum waste produced from phosphate ore processing. Journal of Hazardous Materials, 244-245, 596-602. doi:10.1016/j.jhazmat.2012.10.053

[10] Tayibi, H., Choura, M., López, F.A., Alguacil, F.J. and
López-Delgado, A. (2009) Environmental impact and management of phosphogypsum. Journal Environmental Management, 90, 2377-2386. doi:10.1016/i.jenvman.2009.03.007

[11] Somlai, J., Jobbágy, V., Kovács, J., Tarján, S. and Kovács, T. (2008) Radiological aspects of the usability of red mud as building material additive. Journal of hazardous Materials, 150, 541-545. doi:10.1016/j.jhazmat.2007.05.004

[12] Puertas, F., García-Díaz, I., Barba, A., Gazulla, M.F., Palacios, M., Gómez, M.P. and Martínez-Ramírez, S. (2008) Ceramic wastes as alternative raw materials for Portland cement clinker production. Cement and Concrete Composite, 30, 798-805.

doi:10.1016/j.cemconcomp.2008.06.003

[13] Klover, K. (2009) Radiological constrains of using building materials and industrial by-products in construction. Construction and Building Materials, 23, 246-253. doi:10.1016/j.conbuildmat.2007.12.010

[14] Szabó, Zs., Völgyesi, P., Nagy, H.E., Szabó, Cs., Kis, Z. and Csorba, O. (2013) Radioactivity of natural and artificial building materials-A comparative study. Journal of Environmental Radioactivity, 118, 6474.

doi:10.1016/j.jenvrad.2012.11.008

[15] Deng-Liang, H. Guang-Fu, Y., Fa-Quin, D., Lai-Bao, L. and Ya-Jun, L. (2010) Research on the additives to reduce radioactive pollutants in the building materials containing fly ash. Journal Hazardous Materials, 177, 573-581. doi:10.1016/i.jhazmat.2009.12.071

[16] Sheng-Lung, L., Lai, S.J. and Chian, E.S.K. (1995) Modifications of sulfur polymer cement (SPC) stabilization and solidifications $(\mathrm{S} / \mathrm{S})$ process. Waste management, $\mathbf{1 5}$, 441-447.

[17] EC (1999) Office European Commission Report on Radiological Protection Principles concerning the natural radioactive of building materials, Radiation Protection 112, Official Publications of the European Communities, Luxembourg.

[18] Perez Moreno, P., San Miguel, E.G., Bolivar, J.P. and Aguado, J.L. (2002) A comprehensive calibration method of Ge detector for low level spectrometry measurement. Nuclear Instruments and Methods in Physic Research Section A: Accelerators, Spectrometers, Detectors and Associated Equipment, 491, 152-162. doi:10.1016/S0168-9002(02)01165-8

[19] López-Coto, I., Mas, J.L., Bolivar, J.P. and García-Tenorio, R. (2009) A short time method to measure the radon potential of porous materials. Applied Radiation and Isotopes, 67, 133-138. doi:10.1016/j.apradiso.2008.07.015

[20] STARTcreteTM Technologies INC (2000) Labortory Procedure for Producing STARcretesTM Test Specimens. Technical Report.

[21] López, F.A., Gázquez, M., Alguacil, F.J., Bolívar J.P., García-Díaz, I. and López Coto, I. (2011) Microencapsulation of phosphogypsum into a sulfur polymer matrix: Physico-chemical and radiological characterization. Journal of Hazardous Materials, 192, 234-245.

[22] Sandrolini, F., Manzi S. and Andrucci A. (2006) Sulfurpolymer matrix composites from particulate waste: A sustainable route to advanced materials. Composite Part A: 
Applied Science and Manufacturing, 37, 695-702. doi:10.1016/j.compositesa.2005.07.004

[23] Lembrechts, J., Janssen, M. and Stoop, P. (2001) Ventilation and radon transport in Dutch dwellings computer modeling and field measurement. Science of the Total Environment, 272, 73-78. doi:10.1016/S0048-9697(01)00667-2

[24] Perez-López, R., Nieto, J.M., López-Coto, I., Aguado, J.L., Bolivar, J.P. and Santisteban, M. (2010) Dynamics of contaminants of phosphogypsum or the fertilizer industry of Huelva (SW Spain): From phosphate rock ore to the environment. Applied Geochemistry, 25, 705-715. doi:10.1016/j.apgeochem.2010.02.003

[25] UNSCEAR (1993) sources and effects of ionizing radiation-United Nations Scientific Committee on the effects of Atomic Radiation, UNSCEAR 1993 Report to the General Assembly with Scientific Annexes, New York.

[26] López Coto, I., Mas, J.L., San Migel, E.G., Bolivar, J.P. and
Sengugta D. (2009) A comparison between active and passive techniques for measurements of radon emanation factors. Applied Radiation and Isotopes, 67, 849-853. doi:10.1016/j.apradiso.2009.01.045

[27] Magded, A.F. and Ashraf, F.A. (2005) Radon exhalation rate of some building materials used in Egypt. Environmental Geochemistry and Health, 27, 485-489. doi:10.1007/s10653-005-5332-5

[28] Ackers, J.G., Den Boer, J.F., De Jong, P. and Wolschrijn, R.A. (1985) Radioactivity and radon exhalation rates of building materials in The Netherlands. Science of the Total Environment, 45(C), 151-156. doi:10.1016/0048-9697(85)90215-3

[29] Pereira, C.E., Vaidyan, V.K., Jojo, P.J. and Ramachandran, T.V. (2008) Measurement of radon exhalation rate from building materials used in the southwest coastal region of India. Indoor and Built Environment, 17, 472-475. doi:10.1177/1420326X08095830 